\title{
Features of Spatial-Temporal Hierarchical Structures Formation
}

\author{
Anna Dulfan ${ }^{1}$ (D), and Iryna Voronko² \\ 1 O. M. Beketov National University of Urban Economy in Kharkiv, Kharkiv, Ukraine \\ 2 National Aerospace University "Kharkiv Aviation Institute", Kharkiv, Ukraine
}

\author{
Article History \\ Received: \\ 12 June 2021 \\ Accepted: \\ 11 September 2021 \\ Published online: \\ 29 October 2021

\section{Keywords \\ Dynamic Chaos;} \\ Fractal; \\ Evolution; \\ Hausdorf-Bezikovich \\ Dimension; \\ Topology of Complex \\ Systems
}

\begin{abstract}
The degree of ordering of the structure of technologically important materials formed as a result of the evolution of complex physicochemical systems determines their physical properties, in particular optical. In this regard, the primary task for the theoretical study of methods for obtaining materials with predetermined physical properties is to develop approaches to describe the evolution of fractal (scale-invariant) objects in the formation of self-similar structures in systems exhibiting chaotic behavior. The paper forms an idea of the processes of evolution in materials formed as a result of stochastic processes. It is established that the conduct of ultrametrics in time space allows to characterize the time of the evolutionary process of fractal dimension, which is calculated either theoretically or model. The description of evolutionary processes in a condensed medium, accompanied by topological transformations, is significantly supplemented by the method of describing the stages of evolution of structures, which makes it possible to analyze a wide range of materials and can control their properties, primarily optical. It is shown that the most large-scale invariant structures, due to the investigated properties, can be used as information carriers. It is demonstrated that the presence in physical systems of fractal temporal dimension and generates a self-similar (consisting of parts in a sense similar to the whole object) evolutionary tree, which, in turn, generates spatial objects of non-integer dimension, observed in real situations. On the other hand, temporal fractality provides analysis of systems with dynamic chaos, leading to universal relaxation functions. In particular, in systems with a large-scale invariant distribution of relaxation characteristics, an algebraic law of relaxation is manifested, which leads to rheological models and equations of states, which are characterized by fractional derivatives. It is argued that the fractal dimension of time hierarchies stores information that determines the process of selforganization. Developed in the paper ideas about the processes of building the structure of materials, which lead to the fractal geometry of objects, can be used to predict their properties, in particular, optical.
\end{abstract}

\section{INTRODUCTION}

The optical properties of physical materials are known to be determined primarily by their structure. The problem of determining the mechanisms of structure construction in complex nonlinear systems occupies one of the central places in the natural and technical sciences [1-6].

As Richard Feynman once said, if atoms are arranged somewhere so that their location corresponds to the lowest energy, then elsewhere the atoms dissolve in the same way. In the classic works of Benoit Mandelbrot it is shown that nature prefers the so-called fractal self-similar objects, for which

$$
|\operatorname{dim}(O)-\operatorname{dih}(O)|>0,
$$

where $\operatorname{dim}(O), \operatorname{dih}(O)$ are respectively, the topological dimension and the dimension of HausdorfBezikovich.

The concept of fractal in physics arose when researchers faced the problem of determining the length of the shoreline, and then spread to many physical aggregates, because the real world does not have ideal lines, planes and surfaces [7-11].

At the same time, the theory of dynamic chaos, which together with quantum physics and Einstein's theory of relativity is the basis of the modern natural worldview, argues that dynamic chaos is the result of self-organized criticism. The study of the

Corresponding author: hanna.dulfan@kname.edu.ua (Anna Dulfan)

(C) 2021 The Author(s). Published by O. M. Beketov National University of Urban Economy in Kharkiv Use permitted under Creative Commons Attribution 4.0 International (CC BY 4.0)

Cite as: Dulfan, A., \& Voronko, I. (2021). Features of spatial-temporal hierarchical structures formation. Lighting Engineering \& Power Engineering, 60(2), 66-70. https:/ / doi.org/10.33042/2079-424X.2021.60.2.03 
evolution of real systems with dynamic chaos in the presence of a variety of external influences requires the study of spatiotemporal self-organization, which makes it possible to predict the structure of stable functional states of materials [12-17].

It is known that systems that are sensitive to initial conditions cannot be described within the framework of a deterministic approach, which in a sense requires the transformation of the principle of causality into the principle of correlation.

We show that the possibility of introducing ultrametrics in time space allows us to characterize the time of the evolutionary process in the physical system by fractal dimensionality, which can be obtained theoretically or within the model of a random fractal.

Traditionally called ultrametric is a topological space in which the topology is generated not by a metric but by a function that satisfies the inequality.

$|x+y| \leq(|x|,|y|)$,

and the geometric image of which is the Kaylee tree as shown in graph theory. Each point of the ultrametric space can thus be mapped to an element of a fractal set. Entering a metric on the Kaylee tree allows you to find the distance between any points of the fractal set. Since the value of the set is given by the branching of the Kaylee tree, it means that it is given by the dimension of the corresponding fractal. This statement is true for both a regular tree with a constant branching and a tree that is characterized by branching that varies from node to node. Thus, there is a mutually unambiguous correspondence between the elements of the fractal set and the points of the ultrametric space [18-20].

\section{TEMPORARY HIERARCHICAL STRUCTURES}

Entering a metric on the Kaylee tree allows you to find the distance between any points of the fractal set. Since the value of the set is given by the branching of the Kaylee tree, it means that it is given by the dimension of the corresponding fractal.

To further consider the problem, it is important to note the fact that time space is also ultrametric. In fact, if we enter a logarithmic metric in ordinary time space, we determine the distance between two points $t_{1}$ and $t_{2}$ in time and as follows

$$
\left\{\begin{array}{l}
z\left(t_{1}-t_{2}\right)=\alpha \ln \frac{\left|t_{1}-t_{2}\right|}{\tau}, \\
z \sim 1, \alpha \rightarrow 0, \frac{\left|t_{1}-t_{2}\right|}{\tau} \rightarrow \infty,
\end{array}\right.
$$

where $\alpha$ is the characteristic parameter; $\tau$ is the relaxation time, then

$$
z\left(t_{1}-t_{3}\right)=\max \left\{z\left(t_{1}-t_{2}\right), z\left(t_{2}-t_{3}\right)\right\} .
$$

If we now consider $t_{1}, t_{2}$ and $t_{3}$ as points in time space, then Eq. (3) means that in such a space there are only equilateral and equilateral triangles, which is the property that defines the ultrametric space.

Thus, time space is ultrametric, and therefore is described within the paradigm of fractal geometry.

The presence of physical systems of fractal temporal dimension and generates a self-similar (consisting of parts in a sense similar to the whole object) evolutionary tree, which, in turn, generates spatial objects of non-integer dimension, observed in real situations.

On the other hand, temporal fractality provides analysis of systems with dynamic chaos, leading to universal relaxation functions. In particular, in systems with a large-scale invariant distribution of relaxation characteristics, an algebraic law of relaxation is manifested, which leads to rheological models and equations of states, which are characterized by fractional derivatives.

It can be argued that the fractal dimension of time hierarchies stores information that determines the process of self-organization. How can we not remember the studies of cosmic plasma-powder structures formed in connection with the thermal instability of the environment and are a kind of storage of information that determine the processes of self-organization in structuring the universe, namely: star formation, quasar clusters, planetary rings .

The structure of the so-called "evolutionary fraction" - the unity of the processes of development of matter - is also clarified - the time of processes with a similar structure has the same dimension.

There are many common features of the behavior of complex systems, both physical and chemical, and biological, and physical systems with a complex structure are not simple in morphology or behavior.

The idea of fractal dimensionality of characteristic time, which determines the process of selforganization and formation of evolving structures with dynamic chaos is very important as a tool for describing hierarchical systems, the main property of which is the formation of structures with memory that take information from outside, accumulate it and use it. its optimization.

Thus, the dimension of the characteristic time is not a topological constant. The main methodological tool is the concept of the characteristic time of the evolving system.

Thus, in the physics of thin films, in particular, it has been shown that the same objects in different cases demonstrate the properties of both twodimensional and three-dimensional systems. Thus there is such a section of materials science as the socalled physics of dimension reduction. However, to understand the laws of clustering with a given 
morphological structure requires a universal approach, in which from the traditional calculation of the dimension of the object it is necessary to proceed to the calculation of the evolutionary trajectory of the object (the process of its formation). In the case of the development of the process in the environment excited by him, it is necessary to take into account memory - dependence on previous events. This phenomenon has a temporal dimension - a large-scale indicator of correlation functions.

We can safely say that in the process of evolution of systems with dynamic chaos, there are structures that are characterized by self-similarity. The reason for this is that the very process of development of real systems, their evolution, as a result of which chaos generates order, is a fractal object, ie a structure consisting of parts, in a sense similar to the whole. We see that in the representations of fractal geometry it is possible to describe both the process and its result.

The evolution of systems with dynamic chaos at a distance from equilibrium is a fractal process that generates a fractal structure. Just as a fractal object has a fractional fractal dimension, so a fractal process has an incomplete temporal dimension.

We see that the self-similarity of the evolutionary tree, the unity of the natural evolutionary fragment is explained by the fractality of time hierarchies. If in previous studies the fractal structure of time was adopted a priori, then our approach through the idea of ultrametrics, fractional dimensionality of time acts as a natural consequence of disorder. Determining the large-scale invariance of evolutionary processes greatly simplifies their description. Entering the temporal dimension of the process of selforganization allows us to draw conclusions about the global properties of the development of systems with dynamic chaos and predict the results of their evolution.

Obviously, for standard computer models such as divisional limited aggregation, the fractal dimension of the characteristic evolution time can be obtained by direct processing.

For example, the fractal dimensions of the characteristic time of structures in the model of a random fractal are in the range from 1.1 to 1.5.

As is known, the model of a random fractal describes such real situations as, for example, the growth of a crystal from a binary solution of salolazobenzene under constant temperature gradient, oxidation of amorphous iron films, oxidation of

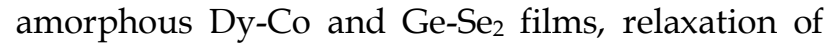
internal stresses by compression $\mathrm{Ni}_{3} \mathrm{Fe}$.

Analysis of the fractal dimensionality of the characteristic time and the actual structural fractal dimensionality of the above structures shows an interesting pattern: if the fractal dimensionality of the characteristic time of the structure formation process is close to unity, then the topology of structures formed in the process of evolution is close to linear. . If the fractal dimension of the characteristic time differs significantly from the integer (as in the case of the growth of a crystal from a binary melt), then the dimension of the fractal structures approaches two.

Let us now turn to the theoretical calculation of the fractal dimension of the characteristic time of evolution of systems from dynamic chaos. This calculation is based on the idea of self-similar - the constancy of the relative growth rate of the system, which is expressed in the large-scale invariance of the process.

The constancy of the relative growth rate of the system is recorded as follows (4):

$$
\lim _{\Delta N, \Delta T \rightarrow 0} \frac{\Delta N}{N-N_{1}}+\frac{T-T_{1}}{\Delta T}=\frac{d \ln \left|N-N_{1}\right|}{d \ln \left|T-T_{1}\right|}=\alpha,
$$

where $N_{1}$ and $T_{1}$ are the reference values of the number of particles and time.

Eq. (4) leads to the fact that self-similar growth must be described by the power law having the form (5):

$N=C\left(T_{1}-T\right)^{\alpha}$,

where $C$ and $\alpha$ are steel, $C$ is the characteristic of the material from the equation, which is calculated for a linear structure, $\alpha$ is the fractal dimension of the characteristic time of the process of structure formation.

If $\alpha=1-$ increase the linear structure. In the case where $\alpha$ differs from 1 are formed large-scale invariant structures, there is a process of selforganization. It is important to emphasize that the theoretical calculation of fractal dimensions of characteristic time, obtained theoretically from Eq. (4) for real systems, coincides with the model calculation for these systems.

So in the study of a number of real structures formed in the process of self-organization in a condensed medium due to the fractal dimensionality of time hierarchies can be carried out purely theoretically in the presence of sufficient factual information about the object being formed (number of structural elements, parameters and boundary conditions of linear structures). Otherwise (lack of factual information, impossibility of selection of factors in which linear structures are formed, etc.) the calculation of fractal dimensionality of characteristic time can be carried out by means of computer modeling of a random fractal.

\section{CONCLUSION}

The analysis of evolutionary processes in condensed media, accompanied by topological transformations 
using the method of predicting the stage of evolution of structures interfacial surfaces in the differentiation of structuring conditions, makes it possible to use it in the study of a wide range of materials, in particular those formed during phase transitions, and thus to predict and influence their properties, including optical. On the other hand, the largest invariant structures due to the identified properties can be used as information carriers at both the micro and macro levels.

\section{DISCLOSURE STATEMENT}

No potential conflict of interest was reported by the author(s).

\section{REFERENCES}

1. Mandelbrot, B.B. (1982). The Fractal Geometry of Nature. Freeman.

2. Mandelbrot, B.B. (2004). Fractals and Chaos. Springer. https://doi.org/10.1007/978-1-4757-4017-2

3. Feder, J. (1988). Fractals. Springer. https:// doi.org/ 10.1007/978-1-4899-2124-6

4. Manuilenko, O.V., Kudin, D.V., Dulphan, A.Y., \& Golota, V.I. (2018). Ozone decay in chemical reactor with the developed inner surface: Air-ethylene mixture. Problems of Atomic Science and Technology, 116(4), 139-143.

5. Petchenko, O.M., Petchenko, G.O., \& Boiko, S.M. (2018). The competition of Mott and Frideel type stoppers as the main blocking mechanisms in mobile dislocations of KBr crystals. Problems of Atomic Science and Technology, 117(5), 24-28.

6. Petchenko, O.M., Petchenko, G.O., Boiko, S.M., \& Bezugly, A.V. (2020). Optical and colorimetrical characteristics of strained $\mathrm{LiF}$ crystals under X-ray irradiation. Problems of Atomic Science and Technology, 126(2), 60-63.

7. Soloviov, S.H. (2019). The fractal nature of strategic communications. Public Administration: Theory and Practice, 1, 33-40. https://doi.org/10.36030/2311-6722-2019-1-33-4 (in Ukrainian)

8. Pustiulha, S., Samchuk, V., Samostian, V., \& Holovachuk, I. (2019). Quantitative analysis of nulldimensional (points) multiplicity by methods of fractal geometry. Applied Geometry and Engineering Graphics, 96, 64-72. https:// doi.org/10.32347/0131-579x.2019.96.64-72 (in Ukrainian)
9. Voss, R.F. (1988). Fractals in nature: from characterization to simulation. In H.O. Peitgen, \& D. Saupe (Eds.), The Science of Fractal Images (pp. 21-70). Springer. https://doi.org/10.1007/978-1-4612-3784-6_1

10. Akhmet, M., Fen, M.O., \& Alejaily, E.M. (2020). Dynamics with Chaos and Fractals. Springer. https://doi. org/10.1007/978-3-030-35854-9

11. Lancia, M.R., \& Rozanova-Pierrat, A. (Eds.). (2021). Fractals in Engineering: Theoretical Aspects and Numerical Approximations. SEMA SIMAI Springer Series, vol. 8. Springer. https:/ / doi.org/10.1007/978-3-030-61803-2

12. Stavrinides S., Ozer M. (Eds.). (2020). Chaos and Complex Systems. SPCOM. Springer. https://doi.org/10. 1007/978-3-030-35441-1

13. Petchenko, G.O., Petchenko, O.M., \& Rokhmanov, M.Y. (2017). Nonmonotonical deformation dependance of color center concentration in functional materials. Lighting Engineering \& Power Engineering, 49(2), 22-24.

14. Petchenko, G.O., Petchenko, O.M., Ovchinnikov, S.S., \& Rokhmanov, M.Y. (2017). The typical absorption in the irradiated by $X$-ray and deformed functional materials. Lighting Engineering \& Power Engineering, 49(2), 30-33.

15. Petchenko, G.O., \& Petchenko, O.M. (2017). Influence of dislocation structure of $\mathrm{LiF}$ crystals on their lighting and colorimetric characteristics. Lighting Engineering $\mathcal{E}$ Power Engineering, 50(3), 25-30. (in Ukrainian)

16. Petchenko, O.M., \& Petchenko, G.O. (2019). Analysis of the results obtained by the method of amplitudeindependent internal friction on metals and ionic crystals. Lighting Engineering \& Power Engineering, 54(1), 30-39. https://doi.org/10.33042/2079-424X-2019-1-54-30-39 (in Ukrainian)

17. Lobanov, Y.E., Nikitsky, G.I., Petchenko, O.M., \& Petchenko, G.O. (2020). The essence and application of the optical absorption method for quantitative and qualitative analysis of radiation defects in optical crystals. Lighting Engineering \& Power Engineering, 59(3), 97-100. https:// doi.org/10.33042/2079-424X-2020-3-59-97-100

18. Banerjee, S., Easwaramoorthy, D., \& Gowrisankar, A. (2021). Fractal Functions, Dimensions and Signal Analysis. UCS. Springer. https://doi.org/10.1007/978-3-030-626723

19. Skiadas, C.H., \& Dimotikalis, Y. (Eds.). (2020). 12th Chaotic Modeling and Simulation International Conference. SPCOM. Springer. https://doi.org/10.1007/978-3-030-395 $15-5$

20. Nigmatullin, R.R., Lino, P., \& Maione, G. (2020). New Digital Signal Processing Methods. Springer. https:// doi.org/10.1007/978-3-030-45359-6

\section{Особливості формування просторово-тимчасових ієрархічних структур}

Ганна Дульфан, Ірина Воронько

Анотація. Ступінь впорядкованості структури технологічно важливих матеріалів, що формуються як результат еволюції складних фізико-хімічних систем, задає їхні фізичні властивості, зокрема оптичні. У зв'язку з цим першочерговим завданням для теоретичного дослідження методів отримання матеріалів із наперед заданими фізичними властивостями є розроблення підходів для опису еволюції фрактальних (масштабно інваріантних) об'єктів при формуванні самоподібних структур в системах, що проявляють хаотичну поведінку. В роботі формується уявлення щодо процесів еволюції у матеріалах, що утворюються в результаті стохастичних процесів. Встановлено, що ведення ультраметрики у часовому просторі дозволяє характеризувати час протікання еволю- 
ційного процесу фрактальної вимірності, що розраховується або теоретично, або модельно. Суттєво доповнений опис еволюційних процесів у конденсованому середовищу, що супроводжується топологічними перетвореннями, за допомогою методики описа стадій еволюції структур, що дає можливість проаналізувати широкий спектр матеріалів і може дозволити керувати їхніми властивостями, в першу чергу оптичними. Показано, що самі масштабно інваріантні структури, завдяки дослідженим властивостям, можуть бути використані в якості носіїв інформацій. Продемонстровано, що наявність у фізичних систем фрактальної часової розмірності і породжує самоподібне (таке, що складається з частин в певному сенсі подібних всьому об'єкту) еволюційне дерево, яке, в свою чергу породжує просторові об'єкти нецілої вимірності, що спостерігаються в реальних ситуаціях. 3 іншого боку, часова фрактальність забезпечує аналіз систем із динамічним хаосом, приводячи до універсальних релаксаційних функцій. Зокрема, в системах із масштабно інваріантним розподілом релаксаційних характеристик проявляється алгебраїчний закон релаксації, що приводить до реологічних моделей і рівнянь станів, яким властиві дробові похідні. Стверджується, що фрактальна розмірність часових ієрархій зберігає інформацію, що визначає процес самоорганізації. Розвинені в роботі уявлення щодо процесів розбудови структури матеріалів, які приводять до фрактальної геометрії об’єктів, можуть бути застосовані для прогнозування їхніх властивостей, зокрема оптичних.

Ключові слова: динамічний хаос, фрактал, еволюція, вимірність Хаусдорфа-Безіковича, топологія складних систем.

\section{NOTES ON CONTRIBUTORS}

\section{Anna Dulfan}

hanna.dulfan@kname.edu.ua

Iryna Voronko

i.voronko@khai.edu
Ph.D., Associate Professor

Department of Physics

O. M. Beketov National University of Urban Economy in Kharkiv, Kharkiv, Ukraine

iD https://orcid.org/0000-0002-7260-6234

p https://publons.com/researcher/AAG-9740-2020

SC https://www.scopus.com/authid/ detail.uri?authorId=9235341900

Ph.D., Associate Professor

Department of Aircraft Manufacturing Technology

National Aerospace University "Kharkiv Aviation Institute", Kharkiv, Ukraine

(iD) https://orcid.org/0000-0002-9689-6977 